\title{
Determination the Effect of Gibberellic Acid Foliar Spray on Growth in Olive Cuttings Cv. Coratina, Chetoui, Megaron under Saline Conditions
}

\author{
Muhammad Arshad Ullah ${ }^{1 *}$, Syeda Sana Aamir¹, Ahmed Behzad ${ }^{2}$ and Summaira Ali ${ }^{1}$ \\ ${ }^{1}$ National Agricultural Research Centre, Pakistan \\ ${ }^{2}$ PMAS Institute of Soil Science and SWC, Pakistan
}

Received: 眥 October 25, 2018; Published: 眥 October 31, 2018

*Corresponding author: Muhammad Arshad Ullah, National Agricultural Research Centre, Pakistan

\begin{abstract}
The study was carried out at NARC Islamabad during July 2018 to October 2018 to examine the impact of gibberellic acid on the 01-year rooted olive cuttings of three varieties i.e. Coratina, Chetoui and Megaron in tunnel under saline environment. Soil salinity was developed artificially with the mixture of different salts at $2.0 \mathrm{dSm}{ }^{-1}$. Completely randomized design was applied with three replications. Foliar spray of Gibberellic acid @ 0, 200 and $400 \mathrm{mgl}^{-1}$ was done. Growth parameters of plant height stem diameter internodal distance, \# of leaves plant ${ }^{-1}$, leaf area, fresh weight, dry weight and chlorophyll contents were recorded at the end of the experiment. Coratina olive variety attained the highest plant height, internodal distance, number of leaves plant ${ }^{-1}$ and leaf area at 200 and $400 \mathrm{mgl}^{-1} \mathrm{GA}_{3}$ foliar spray than other two olive varieties. Stem diameter data indicated similar results in Coratina and Megaron olive varieties that was higher than control. Internodal distance was the maximum at 200 and $400 \mathrm{mgl}^{-1} \mathrm{GA}_{3}$ foliar spray than other two olive varieties in Coratina olive variety. There was no difference in fresh weight of leaves either in $\mathrm{GA}_{3}$ application as well as varieties. Chetoui olive variety gained the highest dry weight of leaves. Chlorophyll contents were gained the highest position by Megaron olive variety at 200 and $400 \mathrm{mgl}^{-1} \mathrm{GA}_{3}$ foliar spray than other two olive varieties under artificially saline conditions.
\end{abstract}

Keywords: Gibberelic acid; Growth hormone; Olea europaea; Coratina; Chetoui; Megaron

\section{Introduction}

Olive is one of the fruit crops that can grow in sandy soil due to its capability to tolerate drought stress. The production of olives in these areas is generally low due to the poor soil fertility and low water holding capacity. According, it seems that trees are not only in need of macronutrients application but also the application of some microelements [1]. The botanical name of the olive plant is "Olea europaea". The olive specie belongs to the family Oleaceae. The history of olive plant is endless and start about 7000 years ago originated from the coastal areas of the Eastern Mediterranean Basin as well as Northern Iraq, and Northern Iran [2]. The native of olive is the Mediterranean, Asia and Africa [3]. Olives are also good source of iron which helps to transport oxygen in blood. Calcium present in olives is essential for bones and muscles [4]. Olive reduced risk of heart diseases and even help to fight cancer [5]. Olive oil is the healthy component of our diet. Oleonalic acid protects liver and improves blood flow [6]. Olives release stress and boost up immune system in human body. Olives contains all essential elements that are necessary for human health. Regularly consuming olives are

good for skin health [7]. One gram of olive oil provides 8 calories energy which is a great source of energy. Olive oil is widely used in industries like food preservation, cookery items and especially in canned products of food industry. Olive oil is also used in cosmetics products and in pharmaceutical industry. 100 milliliter ( $\mathrm{ml}$ ), of one type of olive oil, contains Energy: 800 kcal with Fat: 93.3 g, or which $13.33 \mathrm{~g}$ is saturated, and $66.6 \mathrm{~g}$ is monounsaturated [8]. Olive tree is most common edible plant in the world with average life of 500 years. It can be grown in all types of soil and is moderately salt tolerant crop. Also grow on calcareous soil with pH from 5.6 to 8.5. Olive plant is very slow growing evergreen plant with extensive root system and can also tolerate drought. Mainly grow up to 50 feet in height. Arrangement of leaves is opposite. Most of the olive plants express self-pollination due to hermaphrodite type of flowers. Some cultivars are also exhibit cross-pollination.

The trees are also persistent, easily sprouting back even when cut to the ground [9]. Olive fruit is drupe type when matured is full of edible oil. Olive plant remains productive for very long time if 
manage properly. Olive propagation is done by various methods according to environment susceptibility. Olive is propagated by sexually including seed and asexually including cuttings, layers, grafting etc. Most common and modern propagation technique is cuttings for raising new plants by the help of various growth regulators and in controlled conditions Ullah et al. 2009. Cuttings types include softwood, semi hardwood and hardwood cuttings. Multiplication by hardwood cuttings is common method for raising new plants. Survival rate in hardwood cuttings is high and can tolerate environmental conditions. Desire able traits of parent plants are easily obtained in offspring by cuttings. Genetic makeup of the favorable characteristics easily obtained in new plants [10]. Olive (Olea europaea L.) is considered as the most extensively cultivated fruit crop due to its economic importance and nutritional values. Olive (Olea eurovaea L.) is the most cultivated and earliest fruit tree having an endless history; it covers a region of approximately 7.5 million hectares [11]. According to FAOSTAT, leading world producing countries of olive are Spain and Italy [12]. Exploration survey using morphological features of olive was conducted in Spain, which estimated 262 olive cultivars [13], and there are over 600 cultivars in Italy. Almost 25 olive cultivars are micro propagated and are under study for their performance. The most well documented olive cultivars include oueslati, cv zard, cv rowghani, moraiolo, dolce agogia, leccino, coratina, nocellara, and pendolino. Olive received maximum importance in the Mediterranean region and its cultivation in this region began 6,000 years ago.

The olive fruit is usually oblong in shape, weighing 1 to $10 \mathrm{~g}$ or even more according to the cultivar. The skin of fruit is green when immature and dark blue, blue-violet or black when ripe [14]. Fresh and undressed olives are highly bitter due to a hydro-soluble glycoside called oleuropein. Some olives are naturally sweet due to low oleuropein. The glycoside is hydrolyzed with sodium hydroxide during processing and preserving. Oil can be extracted from fruit juice by hydrolyzing with water. Fresh fruits contain around $80 \%$ unsaturated fatty acids against $20 \%$ saturated ones, $20 \%$ oil and a very low quantity of cholesterol. The importance of olive oil was due to its use in cooking, salad dressing, food preparation, wool treatment, medicine, cosmetics and soap production [11]. Its wood is naturally long-lasting; in southern Italy olive is cultivated as a secondary source of profit [15]. Plant growth regulators are the chemicals that alter the plant growth and change the behavior of different crops. Produced by the plants and also produce artificially to regulate growth and development under various physiological actions. They are also called plant hormones. These hormones are applied to plants in different concentrations in order to control and regulate plant growth in different ways. All functions like normal growth, development, root and shoot growth are control by these hormones [16]. Generally, plant growth regulators are of two types, one is stimulators and other type is inhibitor. Plant growth simulators like auxins, gibberellins and cytokinins promote fruiting, flowering, seed development and cell enlargement. Plant growth is inhibited by abscisic acid result in dormancy and abscission. Auxins promote cell elongation and root initiation in cuttings. Natural auxins like Indole butyric acid (IBA) and Naphthalene acetic acid (NAA) hormones play an important role in root formation of stem cuttings Agusti et al., 2000. Cytokinin helps in cell division. Gibberellins are the very important plant growth regulators and promote cell elongation and also help in fruit developing. Ethylene helps in fruits ripening [17]. Gibberellic acid, also known by $\mathrm{GA}_{3}$ is naturally occurring plant growth hormone that is harvested from fungus and can produce commercially for agriculture and other purposes. In purified form it is white to pale-yellow solid with chemical formula $\mathrm{C}_{19} \mathrm{H}_{22} \mathrm{O}_{6}$. Gibberellic acid discovered by Kurosawa (a Japanese pathologist) from the fungus Gibberrellafujikuroi in 1928 and most common type is $\mathrm{GA}_{3}$. Gibberellins generally stimulate cell division and stem elongation and standardize growth by stretching internodes. $\mathrm{GA}_{3}$ promotes stem elongation. Gibberellic acid plays important role in germination by breaking seed dormancy. $\mathrm{GA}_{3}$ encouraged cell elongation [18,19]. $\mathrm{GA}_{3}$ standardizes flower initiation and development. $\mathrm{GA}_{3}$ contributes in pollination. $\mathrm{GA}_{3}$ improves fruit quality and promote generation of female flowers [20]. $\mathrm{GA}_{3}$ application on olive plants diminishes the chances of alternate bearing in olive plants [21]. GA 3 performs key role in protein synthesis and in regulating nucleic acid. Higher concentration of $\mathrm{GA}_{3}$ can suppress root initiation [22], aids plant to swing at suitable time in reproductive phase [23]. Stem elongation is response of signal transduction pathway with different environmental factors.

There is a great importance of gibberellic acid in agriculture. Foliar application of $\mathrm{GA}_{3}$ increases yield. Also improve the quality of fruits and increase the fruit size [24]. Endogenous gibberellins influence various development processes, such as stem elongation, control various aspects of seed germination, including dormancy break and mobilization of endosperm reserves, moreover, gibberellins influence transition from juvenile stage to mature stage, induction of flowering, sex determination and fruit set establishment in the reproductive development [20]. Gibberellins (GAs) generally regulate growth and encourage stem elongation, flowering, and break seed dormancy, buds, and bulbs, influencing various developmental processes. More than 90 types of gibberellins exist, but $\mathrm{GA}_{3}$ is the most frequently used in tissue culture. Gibberellins are natural stimulators of plant growth and development with frequent spectacular effects and help in obtaining remarkable results in agriculture production, forestry, horticulture and medicinal plants. Gibberellins promote cell division and elongation [25]. Foliar application of $\mathrm{GA}_{3}$ and nutrients had improved the productivity and quality of flowers [26]. Spray olive trees with Gibberellic acid $\left(\mathrm{GA}_{3}\right)$ before an expected "on" year decreased the percentage of opened flower buds per shoot, number 
of flowers per inflorescence in the subsequent year. El-Iraqy, 2001, $\mathrm{GA}_{3}$ are responsible for cell elongation, rather than cell division [17]. Suitable in vitro protocols for olive culturing have been developed; studies indicated that the main factors for achieving elevated growth rates involved in tissue culture include medium formulation [27,28], growth hormones [29], rooting, genotype $[30,31]$ and acclimatization conditions. Olive micro propagation was first studied and documented by [30], who proposed the olive medium $(\mathrm{OM})$, which has been proved to be efficient for the micro propagation of many olive cultivars [29]. Some cultivars do not respond to in vitro conditions due to sensitivity, so their proliferation rate is prolonged, and rooting of explants is also limited, and many plantlets die at the acclimatization stage [32]. The introduction of specific olive medium (OM), [30] for axillary bud stimulation and successive shoot multiplication has paved the way for further advancement of olive micro propagation.

Auxins are the class of plant growth hormones that promotes root initiation by inducing both growth of pre-existing roots and adventitious root formation. The auxin treatment was one of the first factors [33] catch the consideration of researchers for in vitro rooting of shoots [15] as this phytohormone is involved in rooting for so many years and the positive role of various auxins on the initiation and development of rooting is well documented [33]. Exogenous auxin is used as a growth regulator in micro propagation or in vitro culture at a concentration of $0.01-10.0 \mathrm{mg} / \mathrm{L}$. In tissue culture systems, added auxin is generally related to the promotion of growth, induction of rooting, callus induction, cell elongation, tissue swelling, cell division, inhibition of adventitious and axillary shoot formation, and induction of embryogenesis.

In Brazil, olive tree growth is still a recent rural activity in expansion [34], where this country is one of the greatest importers of olive tree products of South America, and, Argentina, one of the greatest suppliers, besides Spain and Portugal [35]. The consumption and imports increase turn the Brazilian market promising for this activity [36]. Furthermore, growth traditional areas in the world are limited to the existing crops, with no significant perspective of increase, making olive trees to gain space in South American countries [37]. In order to reach success in fruit production it is necessary, among other factors, high quality seedlings, with no phytosanitary problems, which present good development when they are combined with adequate handling. The techniques used for spreading olive trees are grafting and rooting. This last one shows lower cost and time to obtain seedling, demanding less qualified labor. But, so that the technique is feasible, according to what Fachinello [38] emphasizes, it demands that the cultivar shows high capacity to form roots, taking into consideration that its root system and later development in the area of production show good quality. Exogenous application of Phyto regulators has been one of the most studied techniques for the improvement of the hormonal balance in rooting, where the indole butyric acid
(IBA) is the most used auxin. Several researches developed towards olive trees rooting have used concentrated hydro alcohol solutions of IBA [34,39-41], therefore, the results found vary a lot according to the dosage, the cultivar, the period of rooting, the substrate and the type of cutting, among other factors. The formation of root primordium cells depends on the endogenous auxins in the cutting and on a synergic compound such as a diphenol. These substances lead to the synthesis of ribonucleic acid (RNA), which act upon root primordium initiation and gibberellins are considered substances that inhibit rooting [22].

$\mathrm{GA}_{3}$ succeeded in inhibition of olive tree blooming in the following season. $\mathrm{GA}_{3}$ has the potential control on growth and flowering process. In addition, increased petiole length, leaf area and delayed petal abscission and color fading (senescence) by the hydrolysis of starch and sucrose into fructose and glucose [42,43], $\mathrm{GA}_{3}$ treatments increase the weight, length, width of olive fruits, stone weight and flesh weight than untreated ones, improvement fruit weight and flesh: seed ratio, [24]. Naphthaleneacetic acid, commonly abbreviated NAA is an organic compound, which is a plant hormone in the auxin family and is an ingredient in many commercial horticultural products; it is also a rooting agent and used for the vegetative propagation of plants from stem and leaf cutting [44]. NAA application at $(100,150) \mathrm{mgL}^{-1} 15$ days after full bloom has been used to chemically thin olives in various countries, NAA has been reported to be useful for thinning of fruits. It has important role in fruit formation, abscission cell elongation, apical dominance, photoperiod and geotropism [45].

The maturity level of sprig, cutting position on the linear length of sprig, type, methods and concentrations of substances rhizogenic, the time necessary for the realization of the rooting process, has great influence on the genetic profile [46,47] Our olive varieties have the various abilities rooting. Being the genetic factor, with difficult rooting varieties continues some research such as: Minimum and maximum the number of buds and leaves, the effect of treatment with different chemical substance through foliar method, etc. $[16,18]$. Salinity stress negatively impacts agricultural yields throughout the world, affecting production, whether for subsistence or economic gain. At present, about $20 \%$ of the world's cultivated land and approximately half of all irrigated land and $2.1 \%$ of the dry agriculture land is affected by salinity [48]. Salinization is spreading more rapidly in irrigated lands because of inappropriate management of irrigation and drainage. Moreover, rain, cyclones and wind add $\mathrm{NaCl}$ to coastal agricultural lands [49]. The rapid increase in the world's population requires an expansion of crop areas to raise food production. Salinity imposes serious environmental problems that affect grassland cover and the availability of animal feed in arid and semiarid regions. Salt stress is one of the most serious limiting factors for crop growth and production in the arid regions. About $23 \%$ of the world's cultivated lands is saline and $37 \%$ is sodic [50]. Considerable research work 
has been conducted on the effect of salinity on different growth characters of different crops worldwide [48,51-57]. Keeping in view this study was planned to increase the growth of olive cutting with foliar spray of Gibbeleric acid under saline conditions.

\section{Materials and Methods}

The study was carried out at NARC Islamabad during July 2018 to October 2018 to examine the impact of gibberellic acid on the 01-year rooted olive cuttings of three varieties i.e. Coratina,
Chetoui and Megaron in tunnel under saline environment. Soil salinity was developed artificially with the mixture of different salts at $2.0 \mathrm{dSm}^{-1}$. Completely randomized design was applied with three replications. Foliar spray of Gibberellic acid @ 0, 200 and $400 \mathrm{mgl}^{-1}$ was done. Growth parameters of plant height stem diameter internodal distance, \# of leaves plant ${ }^{-1}$, leaf area, fresh weight, dry weight and chlorophyll contents were recorded at the end of the experiment. Data were statistically analyzed according to completely randomized design and compared treatment means using LSD test with statistical software, Statistix 8.1 (2005).

\section{Results}

Table1: Impact of Gibberelic acid foliar spray on olive growth under saline environment.

\begin{tabular}{|c|c|c|c|c|c|c|c|c|c|c|c|c|c|c|c|c|c|c|c|c|c|c|c|c|}
\hline \multirow[t]{2}{*}{$\begin{array}{l}\text { Treat- } \\
\text { ment }\end{array}$} & \multicolumn{3}{|c|}{$\begin{array}{l}\text { Plant height } \\
\text { (cm) }\end{array}$} & \multicolumn{3}{|c|}{$\begin{array}{c}\text { Stem } \\
\text { diameter }(\mathrm{cm})\end{array}$} & \multicolumn{3}{|c|}{$\begin{array}{c}\text { Internodal } \\
\text { distance(cm) }\end{array}$} & \multicolumn{3}{|c|}{$\begin{array}{l}\text { \# of leaves } \\
\text { plant-1 }\end{array}$} & \multicolumn{3}{|c|}{$\begin{array}{c}\text { Leaf area } \\
\left(\mathrm{cm}^{2}\right)\end{array}$} & \multicolumn{3}{|c|}{$\begin{array}{l}\text { Fresh weight } \\
\text { of leaves (g) }\end{array}$} & \multicolumn{3}{|c|}{$\begin{array}{l}\text { Dry weight of } \\
\text { leaves (g) }\end{array}$} & \multicolumn{3}{|c|}{$\begin{array}{c}\text { Chlorophyll } \\
\text { Contents (\%) }\end{array}$} \\
\hline & $V_{1}$ & 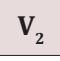 & v & $V_{1}$ & $\mathbf{V}_{2}$ & $V_{3}$ & $V_{1}$ & $\mathbf{v}$ & $\mathbf{V}$ & $\mathrm{V}_{1}$ & $\mathbf{V}_{2}$ & $V_{3}$ & $V_{1}$ & & $\mathrm{~V}$ & $\mathrm{v}$ & & 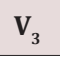 & v & V & v & 1 & 2 & $\mathbf{V}_{3}$ \\
\hline $\mathrm{T}$ & & & & & & & & & & & & & & & & & & & & & & & & 63 \\
\hline $\mathrm{T}_{1}$ & & & & & & & & & & & & & & & & & & & & & & & & 67 \\
\hline $\mathrm{T}$ & & & & & & & & & & & & & & & & & & & & & & & & 69 \\
\hline & 1.2 & & 10 & & & & & & & & & & & & & & & & & 0.5 & & & & 67 \\
\hline
\end{tabular}

$\mathrm{T}_{\mathrm{o}}=0 \mathrm{GA}_{3}, \mathrm{~T}_{1}=200 \mathrm{mgl}^{-1} \mathrm{GA}_{3}, \mathrm{~T}_{2}=400 \mathrm{mg}^{-1} \mathrm{GA}_{3} \mathrm{~V}_{1}=$ Coratina, $\mathrm{V}_{2}=$ Chetoui, $\mathrm{V}_{3}=$ Megaron

Maximum height $(12.6 \mathrm{~cm})$ was attained at $\mathrm{T}_{2}\left(400 \mathrm{mgl}^{-1}\right)$ in Coratina olive variety. Over all Coratina olive cultivar gained the highest plant height i.e., $11.2 \mathrm{~cm}$, and $\mathrm{T}_{2}\left(400 \mathrm{mgl}^{-1}\right)$ displayed second highest plant height is $(10 \mathrm{~cm})$ followed by $9.26 \mathrm{~cm}$ in $\mathrm{T}_{1}\left(200 \mathrm{mgl}^{-1}\right)$ as indicated in Table 1 . Data presented in Table 1 depicted the effects of $\mathrm{GA}_{3}$ foliar application on olive plant stem diameter. Maximum stem diameter $(0.2 \mathrm{~cm})$ was attained at $\mathrm{T}_{2}(400$ $\mathrm{mgl}^{-1}$ ) in two varieties i.e., Coratina and Megaron. Over all Coratina and Megaron olive cultivars gained the highest stem diameter i.e., $0.17 \mathrm{cmand} \mathrm{T}_{2}(400 \mathrm{mg} / \mathrm{l})$ displayed highest stem diameter $(0.18 \mathrm{~cm})$ followed by 0.15 in $_{2}\left(200 \mathrm{mgl}^{-1}\right)$. Data shown in table illustrated the effects of $\mathrm{GA}_{3}$ foliar application on olive plant internodal distance. Highest internodal distance $(1.56 \mathrm{~cm})$ was attained at $\mathrm{T}_{2}\left(400 \mathrm{mgl}^{-1}\right)$ in Coratina olive variety. Overall Coratina olive variety attained the highest internodal distance $(1.44 \mathrm{~cm}) . \mathrm{T}_{2}(400 \mathrm{mg} / \mathrm{l})$ displayed the highest $(1.43 \mathrm{~cm})$ internodal distance followed by $1.29 \mathrm{~cm}$ in $\mathrm{T}_{1}(200$ $\mathrm{mgl}^{-1}$ Data represented in Table 1 showed the effects of $\mathrm{GA}_{3}$ foliar application on olive plant number of leaves. Maximum number of leaves were attained at $\mathrm{T}_{2}\left(400 \mathrm{mgl}^{-1}\right)$ in Coratina olive variety. Overall Coratina olive variety attained the maximum number of leaves (15). $\mathrm{T}_{2}\left(400 \mathrm{mgl}^{-1}\right)$ showed the maximum number of leaves (13.16) followed by $\mathrm{T}_{1}\left(200 \mathrm{mgl}^{-1}\right)$ which attained 11.10 .

Data reported in Table 1 depicted the effects of $\mathrm{GA}_{3}$ foliar application on olive plant leaf area. Maximum leaf area $\left(1.58 \mathrm{~cm}^{2}\right)$ was attained at $\mathrm{T}_{2}\left(400 \mathrm{mgl}^{-1}\right)$ by the Coratina olive cultivar. Overall Coratina olive variety displayed the maximum leaf area $\left(1.47 \mathrm{~cm}^{2}\right)$. $\mathrm{T}_{1}\left(200 \mathrm{mgl}^{-1}\right)$ showed the maximum leaf area $\left(1.36 \mathrm{~cm}^{2}\right)$ followed by $\mathrm{T}_{\mathrm{o}}$ (control) attaining $1.14 \mathrm{~cm}^{2}$. Data presented in Table 1 showed the influences of $\mathrm{GA}_{3}$ foliar application on olive plant leaves fresh weight. Maximum leaves fresh weight $(0.70 \mathrm{~g})$ was attained at $\mathrm{T}_{1}\left(200 \mathrm{mgl}^{-1}\right)$ by the Megaron olive variety. Overall Chetoui olive variety attained maximum leaves fresh weight $(0.64 \mathrm{~g}) . \mathrm{T}_{1}$ (200 $\mathrm{mgl}^{-1}$ ) showed the maximum olive plant leaves fresh weight (0.66g). Data presented in Table 1 showed the effects of $\mathrm{GA}_{3}$ foliar application on olive plant leaves dry weight. Maximum olive plant leaves dry weight $(0.36 \mathrm{~g})$ was attained at $\mathrm{T}_{2}\left(200 \mathrm{mgl}^{-1}\right)$ by the olive variety Chetoui. Over all Chetoui olive variety attained maximum leaves dry weight $(0.33 \mathrm{~g}) . \mathrm{T}_{1}(200 \mathrm{mg} / \mathrm{l})$ and $\mathrm{T}_{2}(400 \mathrm{mg} / \mathrm{l})$ showed the maximum olive plant leaves dry weight $(0.32 \mathrm{~g})$. Data in Table 1 showed the effects of $\mathrm{GA}_{3}$ foliar application on olive plant leaf chlorophyll contents. Highest chlorophyll contents (69.14\%) were attained at $\mathrm{T}_{2}\left(400 \mathrm{mgl}^{-1}\right)$ in Megaron olive variety. Overall Megaron olive variety attained the highest chlorophyll contents $(66.62 \%)$. $\mathrm{T}_{2}\left(400 \mathrm{mgl}^{-1}\right)$ displayed the highest (66.67\%) chlorophyll contents followed by $63.04 \%$ in $\mathrm{T}_{1}\left(200 \mathrm{mgl}^{-1}\right)$.

\section{Discussion}

The results of this study demonstrated that $\mathrm{GA}_{3}$ can play an important role in vegetative growth of olive cuttings. GA foliar application enhances bud sprouting and shoots elongation. $\mathrm{GA}_{3}$ was successfully used by Grigoriadou [27] for shoot proliferation of certain olive tree cultivars. From the above-mentioned results, it was noticed that $\mathrm{GA}_{3}$ foliar sprays at $400 \mathrm{mgl}^{-1}$ concentration was more effective in plant height than spraying $\mathrm{GA}_{3}$ at other concentrations and control. Highest stem diameter was obtained from cuttings sprayed with $\mathrm{T}_{2}\left(400 \mathrm{mgl}^{-1}\right) \mathrm{GA}_{3}$ while control treatment showed 
the lowest diameter of olive cuttings. El-Sharkawy and Mehaisen [58] indicated that application of $\mathrm{GA}_{3}$ on olive plants caused elongation in the primary cells in the young tissues and growth centers. The present results may be attributed to simulative impact of $\mathrm{GA}_{3}$ on cell extension and on cell division. $\mathrm{GA}_{3}$ is an interesting hormone for in vitro shoot elongation of many other species such as Macadamia [59], Acacia [60]. With the $\mathrm{GA}_{3}$ application increasing cell elongation and also increases internodal distance [61]. $\mathrm{GA}_{3}$ foliar application at the concentration of $200 \mathrm{mgl}^{-1}$ has significant effects on olive leaves fresh weight. $\mathrm{GA}_{3}$ foliar sprays at $400 \mathrm{mgl}^{-1}$ and $200 \mathrm{mgl}^{-1}$ concentrations were more effective for olive leaves dry weight as compared to control treatment. This might be due to the fact that, $\mathrm{GA}_{3}$ improve the rate of photosynthesis and cause greater accumulation of photosynthetic [22] which leads to increase in dry matter of plant and significant improvement in absolute growth rate. Highest chlorophyll contents were noted at the treatment of $400 \mathrm{mgl}^{-1}$ in all olive varieties because $\mathrm{GA}_{3}$ may stimulate transport of nutrients through the phloem, modify the strength of the sink by stimulating its growth and increase the ability for sugar unloading from the phloem. Or, they may act on metabolism and compartmentalization of sugar and its metabolites. Being the genetic factor, with difficult rooting varieties continues some research such as: Minimum and maximum the number of buds and leaves, the effect of treatment with different chemical substance through foliar method, etc. [18,19].

\section{Conclusion}

It can be concluded that foliar application of gibberellic acid on olive plants stimulates the growth and development. $\mathrm{GA}_{3}$ application regulates the growth of stems, leaves, buds, height and boost up the plant growth and development characteristics.

\section{References}

1. Ahmed FF and Morsy MH (2001) Response of Canino apricot trees grown in the new reclaimed land to application of some nutrients and ascorbic acid. The fifth Arabian Horti.Conf Ismalia pp. 27-34.

2. Niaz N, Ullah S, Ullah M, Jabeen N (2014) Effect of growth regulators on micro propagation of different olive cultivars (Olea europaea L.). Int Res J of Agri and Aquatic Sci 1(1): 9-14.

3. Mohammed Bahram Kh, Ibrahim M Noori (2008) Effect of Irrigation levels on the growth and yield of olive trees (Olea europaea L cv Ashrasie). Journal of Kirkuk University-Scientific Studies 3(1): 169-184.

4. Lastra A de la, Barranco C, Motilva MDV, Herrerías JM (2001) Mediterranean diet and health: Biological importance of olive oil. Current Pharmaceutical Design 7(10): 933-950.

5. Owen RW, Giacosa A, Hull WE, Haubner R, Wurtele G, et al. (2000 b) Oliveoil consumption and health: the possible role of antioxidants. Lancet Oncology 1(2): 107-112.

6. Visioli F, Galli C, Bornet F, Mattei A, Patelli R, et al. (2000) Olive oil phenolics are dose-dependently absorbed in humans. FEBS Lett 468(23): 159-160.

7. Bianco AD and Uccella N (2000) Biophenolic Components of Olives in Food. Res Int 33(30): 475-485.

8. Moreno JJ, Mitjavilab MT (2003) The degree of unsaturation of dietary fatty acids and the development of atherosclerosis (Review). Journal of Nutritional Biochemistry 14(4): 182-195.

9. Reiger T (2005) The emergence of woods: Attentional learning in form and meaning. Congnitive Science 29(6): 819-865.

10. Davies WJ, Bacon MA, Thompson DS, Sobeih W, Rodriguez LG (2000) Regulation of leaf and fruit growth in plants in drying soil: exploitation of the plants chemical signaling system and hydraulic architecture to increase the efficiency of water use in agriculture. J Exp Bot 51: 16171626.

11. Fabbri A, Lambardi M, Ozden Tokatli Y (2010) Olive breeding. In: Breeding plantation tree Crops: Tropical Species. Springer New York, USA pp. 423-465.

12. FAOSTAT (2009) http://faostat.fao.org/.

13. Barranco D (2009) The varietal Choice in Spain. Olivae 59: 54-58.

14. Martin GC (2009) http://www.nsl.fs.fed.us/wpsm/Olea.pdf.

15. Lambardi M, Rugini E (2002) Micro propagation of olive (Olea europaea L.). In: Micro propagation of woody trees and fruits. Kluwer Academic Publisher Netherland pp. 621-646.

16. Jamal Uddin AFM, Hossan MJ, Islam MS, Ahsan MK, Mehraj H (2012) Strawberry growth and yield responses to gibberellic acid concentrations. J Expt Biosci 3(2): 51-56.

17. Francis D and Srrell DA (2001) The interface between the cell cycle and plant growth.

18. Hannachi, H, Breton C, Msallem M, Ben El Hadj S et al. (2008) Are Olive Cultivars Destinguessable from Oleaster Trees Based on Morphology of Drupes and Pits, Oil Composition and Microsatellite Polymorphisms Acta Botanical Galicia 155 (4): 531-545.

19. Ismaili H (2016) Study of Some forms of IBA in the Rooting Process of the Olive. Int J Curr Microbiol App Sci 5(3): 239-246

20. Taiz L, Zeiger E (2004) Fisiologia Vegetal. Porto Alegre, Artmed pp. 719.

21. Afroz A, Chaudhry Z, Khan, R, Rashid H, Khan SA (2009) Effect of GA on regeneration response of three tomato cultivars (Lycopersicon esculentum). Pak J Bot 41(1): 143-151.

22. Hartmann HT, Kester DE, Davis JFT, Geneve RL (2002) Plant propagation: principles and practices. Prentice Hall, New Jersey, USA.

23. Desouky IM, F Laila Haggag, MMM Abd El Migeed, YFM Fishk et al. (2014) Effect of boron and calcium nutrients sprays on fruit set, oil content and oil quality of some olive oil cultivars. Sci Lett 2(2): 48-52.

24. Ramezani S, A Shekafandeh (2009) Roles of gibberellic acid and zinc sulphate in increasing size and weight of Olive fruit. African Journal of Biotechnology 8(24): 6791-6794.

25. Anonymous (2017) https://tr.wikipedia.org/wiki/Giberellin.

26. Sajjad Y, MJ Jaskani, MY Ashraf, M Qasim, R Ahmad (2014) Response of morphological and physiological growth attributes to foliar application of plant growth regulators in gladiolus White Prosperity. Pak J Agri Sci 51(1): 123-129.

27. Grigoriadou K, Vasilakakis M, Eleftheriou EP (2002) In vitro propagation of the Greek olive cultivar 'Chondrolia Chalkidikis. Plant Cell Tissue Org Cult 71: 47-54.

28. Santos CV, Brito G, Pinto G, Fonseca HMAC (2003) In vitro plantlet regeneration of Olea europaea ssp. maderensis. Scient Hort 97(1): 8387.

29. Chaari Rkhiss A, Maalej M, Drira N (2003) Micro propagation of Tunisian olive varieties: Preliminary results. Olivae 95: 19-23.

30. Zuccherelli G, Zuccherelli S (2002) In vitro propagation of fifty olive cultivars. Acta Hort 586: 931-934.

31. Soumendra KN, Pattnaik S, Chand PK (2000) High frequency axillary 
shoot proliferation and plant regeneration from cotyledonary nodes of pomegranate (Punica granatum L). Scient Hort 85(4): 261-270.

32. Mukerji KG, Manoharachary C (2006) Integration of arbuscular mycorrhizal fungi with micro propagated plants. In: Current concepts in botany, India, IK International Publishing House.

33. Frett NAG, Gett AG, Goulart LWV, Pasquali RR, Termignoni RR, et al. (2001) Distinct effect of auxin and light on adventitious root development in Eucalyptus saligna and Eucalyptus globules. Tree Physiol 21(7): 457464.

34. Oliveira AF de, Chalfun NNJ, Alvarenga AA, Vieira NJ, Pio R, et al. (2009) Olive cutting at different times, substrates and doses of IBA diluted in $\mathrm{NaOH}$ and alcohol. Science and Agrotechnology 33(1): 79-85.

35. Vieira NJ, Oliveira AF, Oliveira NC, Duarte HSS, Gonçalves ED (2008) Technical aspects of the olive tree culture. Belo Horizonte: EPAMIG Technical Bulletin 88(1): 56.

36. Mesquita DL, Oliveira AF, Mesquita HA (2006) Economic aspects of the production and commercialization of olive and olive oil. Agricultural Report Belo Horizonte 27(231): 7-12.

37. Embrapa (2005) Semi-arid and Codevasf evaluate olive trees for the production of olive and olive oil.

38. Fachinello JC, Hoffmann A, Nachtigal JC (2005) Propagation of plantas fruits. Brasilia: Embrapa 2: 221.

39. Sebastiani L, Tognetti R, DI Paolo CP, Vitagliano C (2002) Hydrogen peroxide and indole-3- butyric acid effects on root induction and development in cuttings of Olea europaea L (cv. Frantoio and Gentile di Larino). Advances in Horticultural Science Florença 16(1): 7-12.

40. Oliveira AF de, Pasqual M, Chalfun NNJ, Regina M de A, Rincón C del R (2003) Rooting of semi-olive tree cuttings under different seasons, substrates and concentrations of indolebutyric acid. Science and Agrotechnology 27(1): 117-125.

41. Silva LF de 0 da, Oliveira AF de, Pio R, Zambon CR, Oliveira DL (2012) Rooting of semilenous cuttings of olive cultivars. Bragantia Campinas 71(4): 488-492.

42. Khan AS, NY Chaudhry (2006) $\mathrm{GA}_{3}$ improves flower yield in some cucurbits treated with lead and mercury. Afr J Biotechnol 5(2): 149-153.

43. Emongor VE (2004) Effect of gibberellic acid on postharvest quality and vase life of gerbera cut flowers (Gerbera jamesonii). J Agron (3)3: 191195.

44. Dimitrios, PN, IC Tzanetos, PN Georgia, P Nikos (2008) A portable sensor for the rapid detection of naphthalene acetic acid in fruits and vegetables using stabilized in air lipid films with incorporated auxinbinding protein 1 receptor. Talanta 77(2): 786- 792.

45. Lavee S (2006) Biennial bearing in olive (Olea europaea L). FAO Network Olea 25: 5-12.
46. Fernandes Serrano JM, Serrano MC, Amaral E (2002) Effect of different hormone treatments on rooting of Olea europaea, CV Galega vulgar cuttings. Acta Hort 586: 875-877.

47. Ismaili $H$ (2010) The influence of indole butyric acid (IBA) in different concentrations in the percentage of olive cv. rooting in Albania. AlbShkenca: ALPA 5: 321.

48. FAO (2002) Global network on integrated soil management for sustainable use of salt-affected soils.

49. FAO (2008) Land and Plant Nutrition Management Service.

50. Khan MA, Duke NC (2001) Halophytes-A resource for the future. Wetland Ecology and Management 9(6): 455-456.

51. Munns R (2005) Genes and salt tolerance: bringing them together. New Phytol 167(3): 645-663.

52. Essa TA (2002) Effect of salinity stress on growth and nutrient composition of three soybean (Glycine max (L.) Merrill) cultivars. Journal of Agronomy \& Crop Science 188(2): 86-93.

53. Maghsoudi AM, Maghsoudi K (2008) Salt stress effect on respiration and growth of germinated seeds of different Wheat (Triticum sativum L) cultivars. World J Agri Sci 4(3): 351-358.

54. Cha um S, Pokasombat Y, Kirdmanee, C (2011) Remediation of salt affected soil by gypsum and farmyard manure Importance for the production of Jasmine rice. Aust J Crop Sci 5(4): 458-465.

55. Nasser JY Sholi (2012) Effect of Salt Stress on Seed Germination, Plant Growth, Photosynthesis and Ion Accumulation of four Tomato Cultivars. American Journal of Plant Physiology 7: 269-275.

56. Moradi P, Zavareh M (2013) Effects of salinity on germination and early seedling growth of chickpea (Cicer arietinum L) cultivars. Intl J Farm \& Alli Sci 2(3): 70-74.

57. Zeinolabedin J (2012) The Effects of Salt stress on plant growth. Technical Journal of Engineering and Applied Sciences (TJEAS) 2(1): 7-10.

58. El-Sharkawy SHMM and Mehaisen SMA (2005) Effect of gibberellin and potassium foliage sprays on productivity and fruit quality of guava trees. Egypt J Appl Sci 20(3): 151-162.

59. Mulwa RMS, Bhalla P (2000) In vitro shoot multiplication of Macadamia tetraphylla L Johnson. J of Horti Sci \& Biotech 75(1): 1-5.

60. Vengadesan G, Ganapathi A, Amutha S, Selvaraj N (2003a) Highfrequency plant regeneration from cotyledon callus of Acacia sinuata (Lour) Merr. In Vitro Cell Dev Biol-Plant 39(1): 28-33.

61. Analytical software Statistix 8.1 for Windows (2005) Analytical Software, Tallahassee, Florida, USA.

62. El khawaga, AS (2007) A Improving growth and productivity of Manzanillo olive trees with foliar application of some nutrients and girdling under sandy soil. Journal of Applied Science Research 3(9): 818-822.

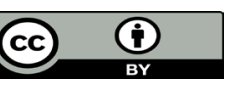

This work is licensed under Creative Commons Attribution 4.0 License

To Submit Your Article Click Here: Submit Article

DOI: 10.32474/CIACR.2018.05.000208

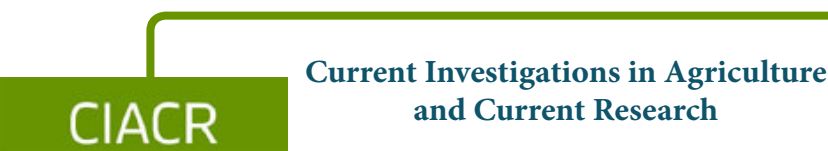

Assets of Publishing with us

- Global archiving of articles

- Immediate, unrestricted online access

- Rigorous Peer Review Process

- Authors Retain Copyrights

- Unique DOI for all articles

Citation: Muhammad A U, Syeda S A, Ahmed B, Summaira A. Determination the Effect of Gibberellic Acid Foliar Spray on Growth in Olive Cuttings Cv. Coratina, Chetoui, Megaron under Saline Conditions. Curr Inves Agri Curr Res 5(2)- 2018. CIACR.MS.ID.000208. DOI: 10.32474/CIACR.2018.05.000208. 